\title{
Research on the Countermeasures of Improving the Practical Ability of College Teachers
}

\author{
Hongchang Wang \\ Jilin Agricultural University, Changchun 130118, China.
}

\begin{abstract}
With the advent of the era of knowledge economy, society has put forward higher requirements for the ability of talents. Colleges and universities are the bases of higher education, and the gathering place of higher talents. College teachers are the main body of higher education institutions; whose level determines the quality of running a College. In order to improve students' practical ability, teachers should first of all improve their practical ability. As the school running conditions are continuously improved, the bottleneck factors which restrict the improvement of educational quality have become more and more focused on the teachers' abilities, especially teachers' practical ability. Through the analysis of existing problems and reasons in the process of cultivating practical ability of teachers in Colleges and universities in China, this paper explores the countermeasures to improve College teachers' practical ability, to provide theoretical basis and decision-making reference for College teachers team construction, and then to achieve the goal of improving the practice ability of the students.
\end{abstract}

Keywords: College teachers; Practical ability; Improvement; Countermeasures.

\section{Introduction}

China's economic and social and the quality of the people are continuously developing and improving. Education, as the main way to improve the quality of the people, over the years has been highly valued by the state, and particular emphasis is put on the promotion of professional teachers' practical ability. However, for the current professional teachers in Colleges and universities, and even some professional teachers of the key institutions of Colleges and universities, there is a great lack of practical ability. The shortage of teachers' practical ability has seriously affected the sustainable development of higher education in our country, which affects the implementation of national talent development strategy, and influences the overall healthy development of China's economic and social development $[1,2]$. But from the study on realistic education, it is found that it is still lacking of taking teachers' practical ability cultivation as a problem to do research and discussion. In consequence, attaching importance to the training of teachers' practical ability, exploring the training mode suitable for China's national conditions, and improving the practical ability of teachers, has become an important issue in the organization and management of Colleges and universities. Therefore, how to improve the practical ability has become an important issue for the university to realize its own development and the function of serving the economic and social development.

\section{Problems and Causes of College Teachers' Practical Ability Cultivation}

In this paper, four representative and different types of Colleges and universities in Xi'an were investigated. They are respectively the comprehensive universities $\mathrm{O}$ and $\mathrm{P}$, a normal universities $\mathrm{Q}$ and a Polytechnic University R, and the survey object is the full-time teachers of the Colleges and universities. The survey uses questionnaire and interview survey these two forms, with a questionnaire based, adopting the way of secret fill-in. Questionnaire is divided into two parts (the first part is basic information of respondents, and the second part is the specific content of answer, with a total design topic of 24, sending out 320 questionnaires, and recover valid questionnaires 286). Through investigation and research on the current situation of cultivation of College teachers' practical ability, lays the foundation for the exploration of the College teachers' practical ability cultivation path. 


\subsection{Single Source Channel and Lack of Professional Practice Background (Table 1 and Table}

2)

Table 1 Statistics of the sources of the full-time teachers

\begin{tabular}{|c|c|c|c|}
\hline Colleges Indexes & Fresh distribution & From Colleges and Universities & Other sources \\
\hline College O & $55 \%$ & $20 \%$ & $10 \%$ \\
\hline College P & $57 \%$ & $17 \%$ & $9 \%$ \\
\hline College Q & $59 \%$ & $24 \%$ & $8 \%$ \\
\hline College R & $68 \%$ & $18 \%$ & $7 \%$ \\
\hline The total & $60 \%$ & $20 \%$ & $10 \%$ \\
\hline
\end{tabular}

Table 2 Statistical table of teachers' practical experience

\begin{tabular}{|c|c|c|c|}
\hline Colleges / Sources of teachers & Directly to teach & Having practical experience in work & Others \\
\hline College O & $53 \%$ & $39 \%$ & $8 \%$ \\
\hline College P & $53 \%$ & $36 \%$ & $11 \%$ \\
\hline College Q & $57 \%$ & $36 \%$ & $7 \%$ \\
\hline College R & $58 \%$ & $30 \%$ & $12 \%$ \\
\hline The total & $57 \%$ & $34 \%$ & $9 \%$ \\
\hline
\end{tabular}

The reasons for the above situation are mainly concluded into the following aspects: 1 Colleges and universities plan to face more to the high level talents in developing recruitment, attaching importance to education level while paying little attention to the ability. 2 . The recruitment conditions of Colleges and universities focuses on the number of scientific research achievements, which limits the entry of skilled talents.

2.2 Seldom Practice Training Channels and Insufficiency in Training Funds (Table 3 and Table 4)

Table 3 Statistics table of teacher training opportunities and needs

\begin{tabular}{|c|c|c|c|}
\hline $\begin{array}{c}\text { Does your school teachers have the opportunity to participate in the enterprise or the } \\
\text { social practice after on-the-job? }\end{array}$ & No & Yes & Others \\
\hline $\begin{array}{c}\text { If there is no allowance, arrange for you to train or study for more than half a year, } \\
\text { would you like to go? }\end{array}$ & $55 \%$ & $36 \%$ & $9 \%$ \\
\hline & Yes & No & Others \\
\hline
\end{tabular}

Table 4 Statistics table of teacher practice training grant funds

\begin{tabular}{|c|c|c|c|c|c|}
\hline \multirow{2}{*}{$\begin{array}{l}\text { What do you think of the subsidy } \\
\text { funds given to the teachers on the } \\
\text { job training by Colleges and } \\
\text { universities at this stage? }\end{array}$} & $\begin{array}{l}\text { Quite } \\
\text { enough }\end{array}$ & $\begin{array}{l}\text { Basically } \\
\text { enough }\end{array}$ & Just so so & Not enough & $\begin{array}{c}\text { Rather } \\
\text { not }\end{array}$ \\
\hline & $5 \%$ & $20 \%$ & $35 \%$ & $30 \%$ & $10 \%$ \\
\hline
\end{tabular}

It can be seen that, at present, influenced by a variety of factors, the policies and measures of the teachers' participation in the enterprises' practice in Colleges and universities have not been truly implemented, let alone being deep into people' heart.

\subsection{Imperfect Performance Evaluation System (Table 5)}

Table 5 Statistics table of teachers' practical skills training system

\begin{tabular}{|c|c|c|c|c|c|}
\hline $\begin{array}{c}\text { Do you think your school attached great } \\
\text { importance to scientific research results } \\
\text { and theoretical teaching and ignore the } \\
\text { practice teaching? }\end{array}$ & No & $\begin{array}{l}\text { Yes, they } \\
\text { attached } \\
\text { importance to. }\end{array}$ & $\begin{array}{l}\text { Comparatively } \\
\text { attached } \\
\text { importance to }\end{array}$ & $\begin{array}{l}\text { Attach } \\
\text { enough } \\
\text { importance to }\end{array}$ & Others \\
\hline results and ignore the practice teaching? & $24 \%$ & $20 \%$ & & $11 \%$ & $4 \%$ \\
\hline \multirow{2}{*}{$\begin{array}{l}\text { Do you think your school is a } \\
\text { professional course in the professional } \\
\text { teachers in the training and training of } \\
\text { professional skills and practical ability? }\end{array}$} & No & $\begin{array}{l}\text { Yes, they } \\
\text { attached } \\
\text { importance to. }\end{array}$ & $\begin{array}{l}\text { Comparatively } \\
\text { attached } \\
\text { importance to }\end{array}$ & $\begin{array}{l}\text { Attach } \\
\text { enough } \\
\text { importance to }\end{array}$ & Others \\
\hline & $50 \%$ & $16 \%$ & $23 \%$ & $8 \%$ & $3 \%$ \\
\hline
\end{tabular}


From the above investigation, it can be seen that those "double teacher type" teachers who have certain teaching and academic level and practical ability often fail to review in senior positions due to the energy dispersion, so these teachers feel that developing "double teacher" is not better to improve the "single teacher", and dampens the enthusiasm of teachers [3]. The reasons for the above problems are mainly the following three aspects: 1 . the evaluation criteria of Colleges and universities emphasize too much on the research results. 2. Attach importance to the research of longitudinal results, while ignore the application of the horizontal results. 3. Pay attention to theory research, while ignore the application transformation.

\section{Countermeasures to Improve the Practical Ability of College Teachers}

\subsection{Broaden the Source Channels of Teachers and Use the System of Probation Period}

In order to enhance the overall practical ability of teachers in Colleges and universities, Colleges and universities can broaden the sources channels of teachers, from the enterprises and scientific research units to introduce personnel so as to enrich teacher's team. But this approach does not assure that universities can recruit the candidates who have strong practice ability.

(1) Adverse Selection Problems in the Recruitment Process of Teachers

Adverse selection refers to in the used car market, because of the information asymmetry, the parties may choose inferior and drive superior product out of the market. That is to say, high ability persons are gradually withdrawing from the market, and only the low ability persons are remained in the market. This is the "adverse selection" problem in the process of teacher recruitment.

(2) Identification of Teachers' Practical Ability Information

In order to reduce the probability of appearance of adverse selection and avoid losses, Colleges and universities can try to use the probation system of hiring new staffs, and stipulate that in the probation period, the person who is not qualified in the assessment will be dismissed. In order to better illustrate the validity of the probation period system, we can use the following game model to demonstrate it.

Set minimum practice ability of the interview personnel required by Colleges and universities is 6 , and real practical ability of the interview personnel is e; length of the probationary period is $\mathrm{T}$, probation salary is $\mathrm{Wi}$, official salary is $\mathrm{W} 2$, the opportunity cost of hiring new staff is $\mathrm{Cu}$, per working years is $\mathrm{T}$, and he future cash flow of the discount factor is 1 . The probability that in the probation period personnel employed by the University is found to have enough practice ability (i.e., qualified in assessment) is $\mathrm{P}(\mathrm{T})$, which is the increasing function about $\mathrm{T}$. That is to say, the longer the probation period, the easier to find out the true level of new hiring staffs, and therefore the greater the possibility to determine they are qualified or not. The specific game model is shown in Figure 1.

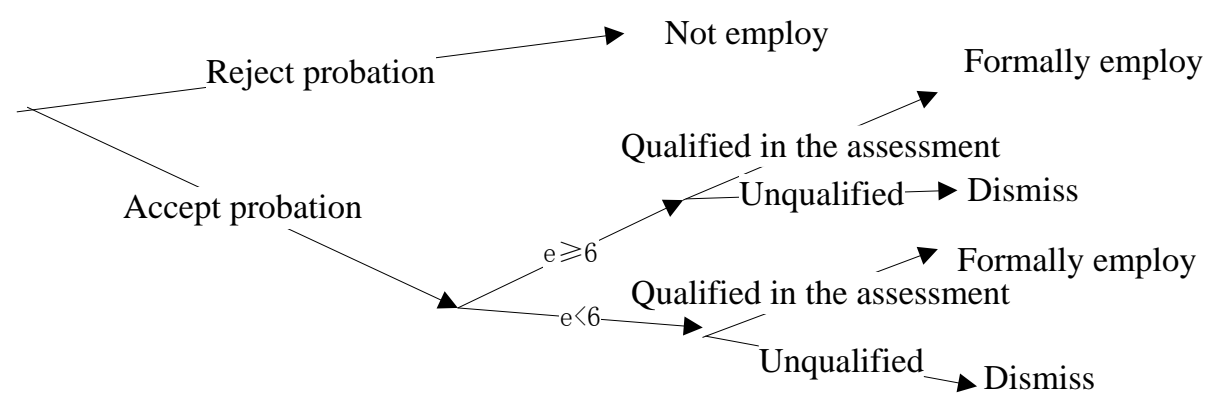

Figure 1 Game model

Through the above game model, it is not difficult to find that the pure strategy is to accept the probation. Within the assessment, staffs who accept probation qualified will be formally employed staffs, and pure strategy for reemployment is "accept or reject probation", so in the case of job seekers to accept the probation, the expected return is as follows [4].

$E(e)= \begin{cases}W_{1} T+W_{2} T_{0} P(T)+C_{u}(e) T_{0}[1-P(T)] & e \geqslant 6 \\ W_{1} T+W_{2} T_{0}[1-P(T)]+C_{u}(e) T_{0} P(T) & e<6\end{cases}$ 


\subsection{Construct the Investment Mechanism of Human Capital in Colleges and Universities and Increasing the Job Training}

The training investment risk of human capital refers to the phenomenon that the training project to invest a certain amount of human, financial and material resources, but in the next few years' investment income cannot compensate for the cost of the investment. That is to say, investment income training income has uncertainty. Colleges and universities are the main part who bear the risks of human capital investment.

Increase in-job training and establish a reasonable training cost sharing mechanism. Under the conditions of special training, teachers' turnover rate is lower than that under the condition of general training. It is because the trainee teachers bear a part of the cost of training, and the obtained special skills cannot be accepted by other universities. Similarly, the university is not willing to dismiss the teacher, because the leave of such kind of teachers will bring losses to the university. As to how much the cost to bear and revenue to share for the two sides can be resolved through consultation between the two sides. In in-job training, teachers should take the majority of the investment of training, Colleges and universities can lend teachers training funds by borrowing agreement, so as to alleviate the economic pressure of teachers.

\subsection{Improve the Performance Evaluation System of Teachers in Colleges and Universities and Pay Attention to the Application of Research}

With the development of economy and society, more and more management and research have realized the limitations and shortcomings of the single performance appraisal subject. With the popularity of the 360-degree performance feedback method, the participants of the evaluation are also increasingly diversified. The teacher's leadership, colleagues, students and enterprises can become the main body of the evaluation of teacher performance. By constructing a diversified performance evaluation subject, it is no doubt that it can reduce the evaluation error and obtain an objective and fair evaluation of the teacher's performance [5]. Universities should take the following measures to improve the reliability and validity of performance information: do relevant cultivation of the reviewers, pay attention to the performance communication, and establish and improve the integrity of the system. According to the established performance evaluation index system, the weight is determined by application level analysis method, and the evaluation results of the preparation stage, the implementation stage and the post implementation stage are calculated by using the fuzzy comprehensive evaluation method. Through the evaluation, find the shortcomings, further optimize the indicators, and promote the quality of teacher performance evaluation.

\subsection{Optimize the Incentive Model in Colleges and Universities}

From the experience point of view, the method of mobilizing people's ability is of variety. The first one is to force, which usually plays a role in simple labor, but the complex labor cannot be sustained. The second is to rely on enthusiasm, similar to the faith. It has certain functions but they are not universal. The third is to exchange. The more important, universal, and durable approach to mobilize human capital should be to exchange. As a knowledge worker, College teachers not only desire to get an enviable income, but also expect to get the respect of others and a sense of accomplishment in business, and enhance the value of human capital [6]. Adopt variable salary system, implement performance pay system. Through the implementation of variable pay system, link the performance assessment and teacher's practical ability training, encourage teachers to constantly improve their practical ability, so as to improve the overall level of Colleges, enhance the school management performance and promote teachers' practical ability cultivation.

\section{Conclusion}

With the development of economy and society, higher and higher requirements have been put forward on the ability of talents. Teachers, as the main body of the Colleges, are the supervisor for students to make progress in their knowledge and ideas, and teacher's words and deeds will both produce a subtle effect on students. To improve the practical ability of students, the goal is the student 
and the key lies in the teachers, so first of all, we must improve teachers' practical ability. This paper, in view of the current situation of university practical ability training, the method of combining the theoretical research on and investigation is adopted to analyze teachers' practical ability training problems and causes, and the measures and suggestions of the cultivation of practical ability are put forward. The research on the cultivation of teachers' practical ability is still developing, and researches on practical ability is deepening. In consequence, this paper's research results also need to be further improved and enriched in practice.

\section{References}

[1] Bogert N, Crasborn F, and Bruggen J. Eliciting mentor and pre-service teachers' practical knowledge using teacher-tagged classroom situations: Making teaching explicit: Approaches to assisting student teacher learning in practice [J]. 2014.

[2] ZHANG C, ZHANG G, WANG Q. Reflections on the Training of Practical Ability for Teachers in Universities Majoring in Civil Engineering [J]. Journal of Langfang Teachers College (Natural Science Edition), 2014, 2: 036.

[3] Wei W, Zhongwen L, Xiying Z. A Brief Discussion on the Training of Engineering University Students' Innovative Practical Ability: Exemplified by Students' Participation in Innovative Experiments Guided by Teachers [J]. The Science Education Article Collects, 2014, 4: 039.

[4] Chunhua L. Mode Exploration of Practical Ability Cultivation Mode for English Talents Based on Integration of Industry Study and Research in College [J]. 2014.

[5] LIU H, LIU Y, HAN H. Cultivation of the students' professional practical ability in engineering course teaching-A case of the Teaching Practice of Water Resources Planning \& Using[J]. Journal of Agricultural University of Hebei (Agriculture and Forestry Education Edition), 2013, 2: 022 .

[6] Ren X G, Cui Y M. An innovative research on autonomous learning ability's cultivation for the college students majoring in art design[C] MATEC Web of Conferences. EDP Sciences, 2016, 63: 01029. 